\title{
Nanocoating of magnetic cores with sulfonic acid functionalized shells for the catalytic dehydration of fructose to 5-hydroxymethylfurfural
}

\author{
Xiaochen Zhang a, Min Wang a, Yehong Wang a, Chaofeng Zhang a,b, Zhe Zhang a,b, Feng Wang a,*, \\ Jie Xu ${ }^{a, \#}$ \\ a State Key Laboratory of Catalysis, Dalian National Laboratory for Clean Energy, Dalian Institute of Chemical Physics, Chinese Academy of Sciences, \\ Dalian 116023, Liaoning, China \\ ${ }^{\mathrm{b}}$ Graduate University of Chinese Academy of Sciences, Beijing 100049, China
}

\section{A R T I C L E I N F O}

Article history:

Received 21 September 2013

Accepted 23 October 2013

Published 20 May 2014

\section{Keywords:}

Magnetic particle

Nanocatalyst

Fructose dehydration

5-Hydroxymethylfurfural

Sulfonic acid

\begin{abstract}
A B S T R A C T
A magnetically recyclable acid catalyst composed of an $\mathrm{Fe}_{3} \mathrm{O}_{4}$ core and sulfonic acid functionalized silica shell has been prepared using the reverse microemulsion method. $\mathrm{The} \mathrm{Fe}_{3} \mathrm{O}_{4}$ core was coated with a phenyl modified silica shell nanolayer, and the phenyl groups were subsequently sulfonated to generate a solid sulfonic acid catalyst. The resulting acid catalyst showed higher activity than the conventional A-15 catalyst and comparable activity to several homogeneous sulfonic acid catalysts for the dehydration of fructose to 5-hydroxymethylfurfural (HMF). This process gave a fructose conversion of $99 \%$ with an HMF yield of $82 \%$ following $3 \mathrm{~h}$ in dimethylsulfoxide at $110{ }^{\circ} \mathrm{C}$. Furthermore, the catalyst could be magnetically separated and recycled several times without losing its activity.
\end{abstract}

(C) 2014, Dalian Institute of Chemical Physics, Chinese Academy of Sciences. Published by Elsevier B.V. All rights reserved.

\section{Introduction}

In recent years, the conversion of biomass into chemicals of commercial value has attracted considerable levels of attention [1-4]. 5-Hydroxymethylfurfural (HMF) can be derived from sugars and is considered to be an important platform molecule in terms of its ability to be transformed into a variety of fine chemicals or biofuels [5-9].

Significant research efforts have been directed towards the development of methods for the preparation of HMF via the acid catalyzed dehydration of fructose. Homogeneous catalysts generally show high levels of efficiency towards the catalytic dehydration of fructose to HMF, and a number of different catalysts have been investigated for this purpose, including mineral acids [10,11], organic acids [12], Lewis acids [13-15], and ionic liquids $[3,16]$. Although excellent yields have been achieved for the dehydration of fructose to HMF using homogeneous catalysts, the development of heterogeneous catalytic systems for this transformation is highly desired because of the ease with which these systems can be separated from the reaction mixture and recycled. Solid acid catalysts, such as niobium oxide [6], phosphate [17], H-form zeolites [18], sulfated zirconia [19], and acidic ion-exchange resins [5,20] have been used for the dehydration of fructose. Among the acid catalysts tested,

\footnotetext{
* Corresponding author. Tel/Fax: +86-411-84379762; E-mail: wangfeng@dicp.ac.cn

\# Corresponding author. Tel/Fax: +86-411-84379245; E-mail: xujie@dicp.ac.cn

This work was supported by the National Natural Science Foundation of China $(21073184,21273231$, and 21233008) and Hundred Talents Program of the Chinese Academy of Sciences.

DOI: 10.1016/S1872-2067(12)60739-6 | http://www.sciencedirect.com/science/journal/18722067 | Chin. J. Catal., Vol. 35, No. 5, May 2014
} 
those bearing sulfonic acid groups have been shown to be particularly efficient. Conventional solid sulfonic acids, however, such as A-15 and Nafion NR50 [20] are not readily accessible to the substrates because of their bulky character and generally show lower activity than homogenous catalysts. One general way to overcome this problem is to disperse the solid acid sites or to graft the acid groups onto porous materials to maximize the exposure of the substrate to the acidic sites [21-23]. The development of new strategies capable of providing substrates with greater exposure to the active sites of the catalyst, as well as allowing for the facile separation of the catalyst at the end of the reaction, still represents a significant challenge to the design of heterogeneous acid catalysts.

In this study, we developed a nanocoating method capable of effectively exposing the active sites on the outer surface of magnetic nanoparticles (MNPs) as well as allowing for the catalyst to be separated and recycled using magnetic force. In contrast to previously reported magnetically recyclable catalysts with bulk character, the current study involves extremely thin (4 nm) sulfonic acid functionalized silica shells that were coated onto $\mathrm{Fe}_{3} \mathrm{O}_{4}$ nanocores of $10 \mathrm{~nm}$ in diameter. These characteristics were favorable for the diffusion of molecules, and the catalysts themselves showed higher activity than the conventional solid sulfonic acid catalyst A-15 and comparable levels of activity to the homogeneous sulfonic acid catalysts for the dehydration of fructose to HMF. This process gave $99 \%$ fructose conversion with an HMF yield of $82 \%$. Furthermore, the catalyst could be magnetically separated and recycled several times.

\section{Experimental}

\subsection{Preparation of $\mathrm{Fe}_{3} \mathrm{O}_{4} @ \mathrm{Si} / \mathrm{Ph}-\mathrm{SO}_{3} \mathrm{H}$}

The MNPs were prepared according to a previously reported procedure [24-26]. Briefly, $25 \mathrm{~mL} \mathrm{NH}_{4} \mathrm{OH}$ solution (28 wt\%) was rapidly added to a solution of $\mathrm{FeSO}_{4} \cdot 7 \mathrm{H}_{2} \mathrm{O}(2.35 \mathrm{~g})$ and $\mathrm{FeCl}_{3} \cdot \mathrm{H}_{2} \mathrm{O}(4.1 \mathrm{~g})$ in $100 \mathrm{~mL}$ deionized water at room temperature, and the resulting solution was mechanically stirred in an oil bath at $80^{\circ} \mathrm{C}$ under an Ar atmosphere. During the course of the reaction, oleic acid ( $1 \mathrm{~mL}$ ) was slowly added to the reaction mixture in a drop-wise manner over a period of $1 \mathrm{~h}$. The resulting MNPs were washed with ethanol before being transferred with a magnet and dispersed in cyclohexane $(50 \mathrm{~mL})$.

The $\mathrm{Fe}_{3} \mathrm{O}_{4} @ \mathrm{Si} / \mathrm{Ph}$ was prepared using a water-in-oil reverse microemulsion according to our previously reported method [27]. Poly(oxyethylene)nonylphenol ether (NP-7, $8 \mathrm{~g}$ ), $n$-butanol (15 g), cyclohexane $(25 \mathrm{~mL})$, water $(5.5 \mathrm{~g})$, and aqueous ammonia ( $2 \mathrm{~g}$ ) were mixed with the cyclohexane solution of MNPs (5 mL) prepared above to give a microemulsion. Tetraethoxysilane (TEOS, $1.0 \mathrm{~g}$ ) and phenyltriethoxysilane (PTES, $0.4 \mathrm{~g}$ ) were then slowly added to the microemulsion in a drop-wise manner. The mixture was stirred for $12 \mathrm{~h}$ and then treated with ethanol to destroy the microemulsion. The resulting solid material was collected and washed twice with ethanol to remove the surfactants before being dried at $100{ }^{\circ} \mathrm{C}$. The dried powder $(0.3 \mathrm{~g})$ was re-dispersed in $15 \mathrm{~mL}$ of fuming sul- furic acid (15 $\mathrm{wt} \% \mathrm{SO}_{3}$ ) under ultrasonic irradiation at room temperature for $30 \mathrm{~min}$, and then washed repeatedly with hot distilled water until the $\mathrm{pH}$ of the supernatant liquid was neutral. The $\mathrm{Fe}_{3} \mathrm{O}_{4} @ \mathrm{Si} / \mathrm{Ph}-\mathrm{SO}_{3} \mathrm{H}$ material was obtained after drying at $100{ }^{\circ} \mathrm{C}$.

\subsection{Characterization}

The microstructures of the materials were examined by transmission electron microscopy (TEM) on a JEOL JEM-2000 EX electron microscope (Japan) at an accelerating voltage of $120 \mathrm{kV}$. The morphologies of the materials were determined by scanning electron microscopy on a JSM-7800F system (Japan). The infrared (FT-IR) spectra were measured as $\mathrm{KBr}$ disks on a Bruker Tensor 27 FT-IR spectrometer (Germany) with 16 scan at a resolution of $4 \mathrm{~cm}^{-1}$. The thermal stability data were collected on a Netzsch STA 409 PC (Germany) and ThermoStar ${ }^{\mathrm{TM}}$ (Germany) using $\mathrm{O}_{2}$ as a carrier gas with a gas flow of 40 $\mathrm{mL} / \mathrm{min}$. The acidities of the materials were determined using a Mettler Toledo G20 Compact Titrator (Switzerland). The X-ray diffraction (XRD) patterns were measured on a Rigaku D/max 2500 PC X-ray diffractometer (Japan) with $\mathrm{Cu} K_{\alpha}$ radiation (tube voltage $40 \mathrm{kV}$, tube current $30 \mathrm{~mA}$, scan rate $10^{\circ} \mathrm{C} / \mathrm{min}$ ). Nitrogen adsorption-desorption isotherms were measured on a QuadraSorb SI4 system (USA).

\subsection{Acidity titration}

n-Butylamine was dissolved in acetonitrile in a $500 \mathrm{~mL}$ volumetric flask to give a $12.34 \mathrm{~mol} / \mathrm{L}$ solution of $n$-butylamine. A quantity of $\mathrm{Fe}_{3} \mathrm{O}_{4} @ \mathrm{Si} / \mathrm{Ph}-\mathrm{SO}_{3} \mathrm{H}$ materials was dissolved in 50 $\mathrm{mL}$ acetonitrile, and the solution was stirred $30 \mathrm{~min}$ in the titrator to equilibrate electric potential. The system was then flushed with the above $n$-butylamine solution, and the electrode was inserted. The above $n$-butylamine-acetonitrile solution was then titrated according to the incremental titration method. The VEQ value (i.e., the consumption volume of $n$-butylamine-acetonitrile at the equivalence point) was then obtained, and the average acid density of the solution was calculated to be $12.43 \mu \mathrm{moL} / \mathrm{g}$ (sample). The acidity of A-15 was also measured under the same conditions for comparison (Table 1).

\subsection{Catalytic reaction}

For a typical catalytic reaction, fructose $(0.02 \mathrm{~g})$ and the catalyst (0.01 g) were mixed in dimethylsulfoxide (DMSO, $1.0 \mathrm{~mL}$ ). The catalytic reaction was conducted at a variety of different temperatures over specific times under Ar with stirring. At the end of the reaction, the catalyst was separated from the mixture by magnetic force, and the reaction solution was analyzed by liquid chromatography on an Agilent 1260 Infinity system (USA). The conversion was measured on a PrevaiL Carbohydrate ES column ( $5 \mu \mathrm{m}, 4.6 \mathrm{~mm} \times 250 \mathrm{~mm}$ ) using a mobile phase composed of acetonitrile and water $(75: 25, \mathrm{v} / \mathrm{v})$ with a flow rate of $1 \mathrm{~mL} / \mathrm{min}$. The column and detector were operated at $35{ }^{\circ} \mathrm{C}$, and an injection volume of $20 \mu \mathrm{L}$ was used for the 
Table 1

Physical properties of the nanomaterials and A-15.

\begin{tabular}{lcccc}
\hline Sample & $\begin{array}{c}\text { Acid density }^{\mathrm{a}} \\
(\mathrm{mmol} / \mathrm{g})\end{array}$ & $\begin{array}{c}A_{\text {BET }} \\
\left(\mathrm{m}^{2} / \mathrm{g}\right)\end{array}$ & $\begin{array}{c}\text { Vpore } \\
\left(\mathrm{cm}^{3} / \mathrm{g}\right)\end{array}$ & $\begin{array}{c}\text { Vpore } \\
\left(\mathrm{cm}^{3} / \mathrm{g}\right)\end{array}$ \\
\hline $\mathrm{Fe}_{3} \mathrm{O}_{4} @ \mathrm{Si} / \mathrm{Ph}$ & - & 69.8 & 0.1785 & 0.0049 \\
$\mathrm{Fe}_{3} \mathrm{O}_{4} @ \mathrm{Si} / \mathrm{Ph} \mathrm{SO}_{3} \mathrm{H}$ & 0.01243 & 138.1 & 0.2544 & 0.0185 \\
$\mathrm{~A}-15$ & 2.27 & $42^{\mathrm{d}}$ & $0.36^{\mathrm{d}}$ & - \\
\hline
\end{tabular}

a Calculated by titration.

b Total pore volume with $p / p_{0}=1$.

${ }^{\mathrm{c}}$ Micropore volume calculated using the $t$-method.

${ }^{\mathrm{d}}$ As reported by Singh [28].

analyses. The yield was measured with a ZORBAX SB-C18 column ( $5 \mu \mathrm{m}, 4.6 \mathrm{~mm} \times 150 \mathrm{~mm})$ using a mobile phase composed of methanol and water $(20: 80, \mathrm{v} / \mathrm{v})$ with a flow rate of 0.7 $\mathrm{mL} / \mathrm{min}$. The column and detector were operated at a temperature of $35{ }^{\circ} \mathrm{C}$ and an injection volume of $2.5 \mu \mathrm{L}$ was used for the analyses. The conversion of fructose and yield of HMF were quantified using external standards.

\section{Results and discussion}

As shown in Scheme 1, the magnetic $\mathrm{Fe}_{3} \mathrm{O}_{4}$ particles were prepared via the co-precipitation of $\mathrm{FeSO}_{4}$ and $\mathrm{FeCl}_{3}$. TEM images of the particles (Fig. 1) revealed that the mean diameter of

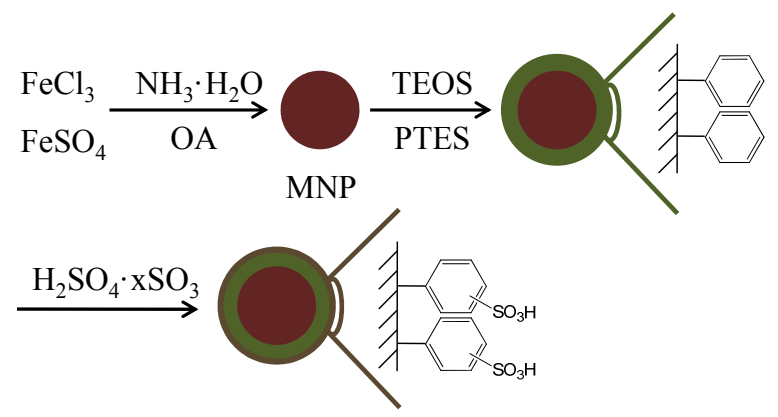

Scheme 1. Preparation of the magnetic solid nanoparticles with core/ shell structure. MNP: magnetic nanoparticle; TEOS: tetraethoxysilane; PTES: phenyltriethoxysilane.
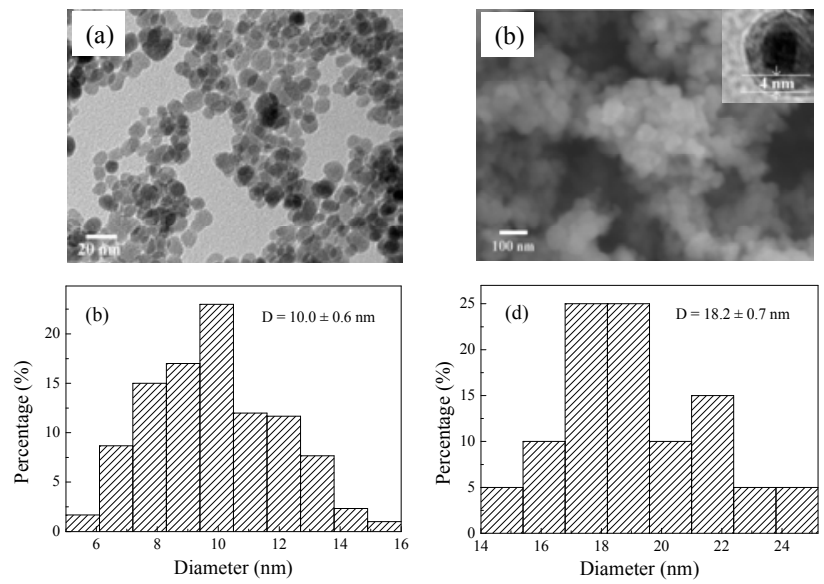

Fig. 1. TEM image (a) and the corresponding particle size distribution plot (b) for the $\mathrm{Fe}_{3} \mathrm{O}_{4}$.particles; SEM image (c) of the $\mathrm{Fe}_{3} \mathrm{O}_{4} @ \mathrm{Si} / \mathrm{Ph}-\mathrm{SO}_{3} \mathrm{H}$ particles (the insert is a TEM image of a single particle) and the corresponding particle size distribution plot (d).

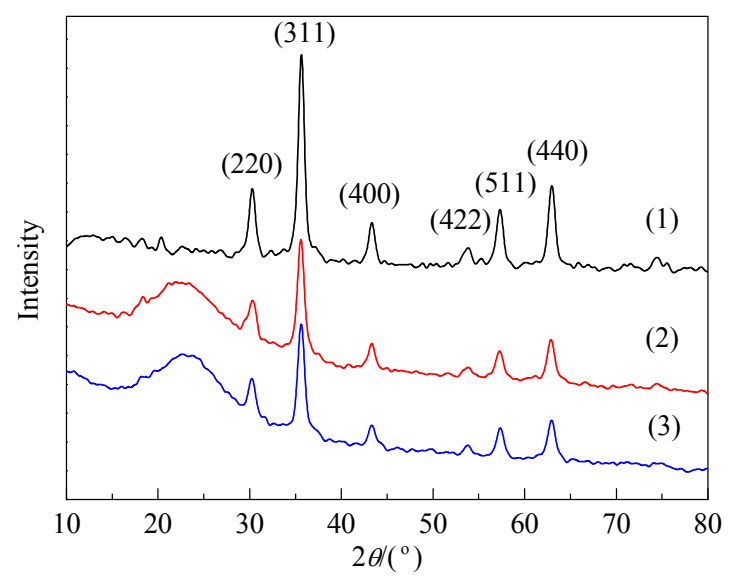

Fig. 2. XRD patterns of $\mathrm{Fe}_{3} \mathrm{O}_{4}$ (1), $\mathrm{Fe}_{3} \mathrm{O}_{4} @ \mathrm{Si} / \mathrm{Ph}(2)$, and $\mathrm{Fe}_{3} \mathrm{O}_{4} @ \mathrm{Si} /$ $\mathrm{Ph}-\mathrm{SO}_{3} \mathrm{H}(3)$.

the resulting $\mathrm{Fe}_{3} \mathrm{O}_{4}$ nanoparticles was around $10 \mathrm{~nm}$. These $\mathrm{Fe}_{3} \mathrm{O}_{4}$ particles were then coated with a phenyl functionalized silica nanoshell of about $4 \mathrm{~nm}$ in thickness ( $\mathrm{Fe}_{3} \mathrm{O}_{4} @ \mathrm{Si} / \mathrm{Ph}$ ) using the reverse microemulsion method. The resulting $\mathrm{Fe}_{3} \mathrm{O}_{4} @$ $\mathrm{Si} / \mathrm{Ph}$ particles were then treated with oleum to allow for the introduction of the sulfonic acid groups. Following the silica coating process, an amorphous silica peak around $23^{\circ}$ appeared in the XRD pattern of the material (Fig. 2). The XRD patterns of $\mathrm{Fe}_{3} \mathrm{O}_{4} @ \mathrm{Si} / \mathrm{Ph}$ and $\mathrm{Fe}_{3} \mathrm{O}_{4} @ \mathrm{Si} / \mathrm{Ph}-\mathrm{SO}_{3} \mathrm{H}$ were almost identical, which indicated that the $\mathrm{Fe}_{3} \mathrm{O}_{4}$ core had not been destroyed during the sulfonation process because of the protection afforded by the silica shells. Furthermore, the magnetism of the core was preserved, with the particles responding quickly to the presence of a magnet (Fig. 3). The TEM and SEM images of the material clearly showed that the $\mathrm{Fe}_{3} \mathrm{O}_{4} @ \mathrm{Si}$ / $\mathrm{Ph}-\mathrm{SO}_{3} \mathrm{H}$ particles synthesized in the current study were nanoparticles with a typical core-shell structure. The surface area and pore volume for the $\mathrm{Fe}_{3} \mathrm{O}_{4} @ \mathrm{Si} / \mathrm{Ph}$ and $\mathrm{Fe}_{3} \mathrm{O}_{4} @ \mathrm{Si} / \mathrm{Ph}-\mathrm{SO}_{3} \mathrm{H}$ particles were 69.8 and $138.1 \mathrm{~m}^{2} / \mathrm{g}$ and 0.18 and $0.25 \mathrm{~cm}^{3} / \mathrm{g}$, respectively (Table 1 ). The observed increases in these values were attributed to the formation of pores in the particles during the sulfonation process.

The compositions of the materials were characterized by

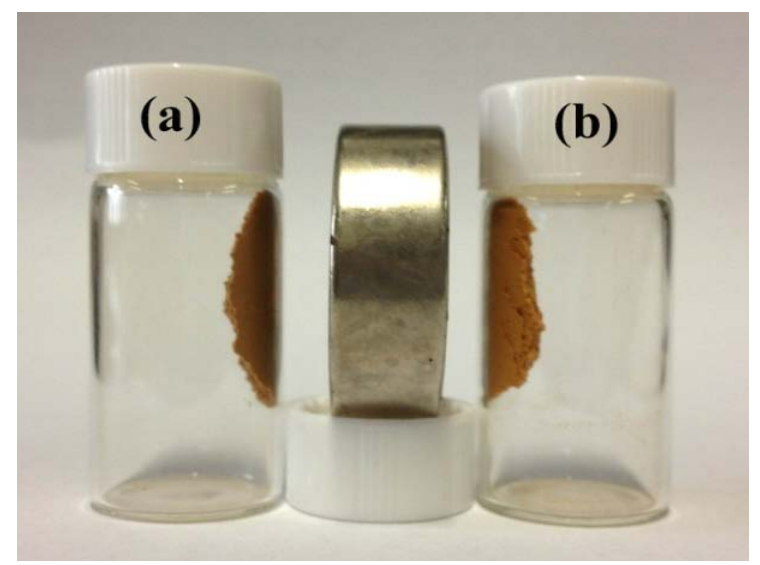

Fig. 3. Magnetic performance of the nanomaterial before (a) and after (b) sulfonation. 


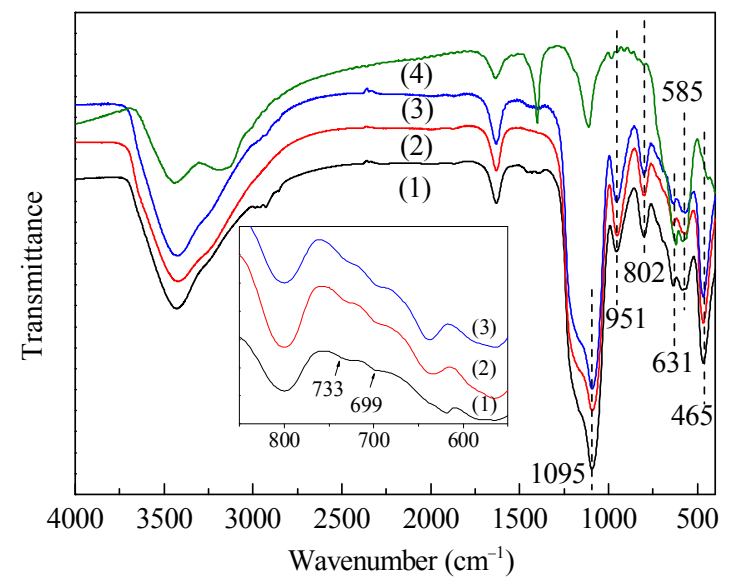

Fig. 4. FT-IR spectra of $\mathrm{Fe}_{3} \mathrm{O}_{4} @ \mathrm{Si} / \mathrm{Ph}(1), \mathrm{Fe}_{3} \mathrm{O}_{4} @ \mathrm{Si} / \mathrm{Ph}-\mathrm{SO}_{3} \mathrm{H}$ (2), the used $\mathrm{Fe}_{3} \mathrm{O}_{4} @ \mathrm{Si} / \mathrm{Ph}-\mathrm{SO}_{3} \mathrm{H}(3)$, and $\mathrm{Fe}_{3} \mathrm{O}_{4}$ (4).

FT-IR (Fig. 4). Typical bands associated with the formation of a condensed siloxane network were present in the spectra of the $\mathrm{Fe}_{3} \mathrm{O}_{4} @ \mathrm{Si} / \mathrm{Ph}$ and $\mathrm{Fe}_{3} \mathrm{O}_{4} @ \mathrm{Si} / \mathrm{Ph}_{-} \mathrm{SO}_{3} \mathrm{H}$ particles (Si-O-Si bands around 1095, 802, and $465 \mathrm{~cm}^{-1}$ ). The peak at $951 \mathrm{~cm}^{-1}$ was attributed to the different modes of the $\mathrm{Si}-\mathrm{OH}$ bond. Weak peaks characteristic of phenyl ring vibrations were detected at 733 and $699 \mathrm{~cm}^{-1}$ in the enlarged spectra, which indicated that the phenyl groups had been successfully attached to the material $[27,29,30]$. Following the sulfonation process, the resonance peaks assigned to the $-\mathrm{SO}_{3} \mathrm{H}$ groups around 1035 and $1215 \mathrm{~cm}^{-1}$ [31], overlapped with the $\mathrm{Si}-\mathrm{O}-\mathrm{Si}$ bond vibration peaks. However, the sulfur element was detected by energy-dispersive X-ray spectroscopy (EDX, $0.07 \mathrm{wt} \%$ ). The bands at 631 and $585 \mathrm{~cm}^{-1}$ belonging to $\mathrm{Fe}_{3} \mathrm{O}_{4}$ had shifted slightly because of the effect of the siloxane network [26].

The thermal stability of $\mathrm{Fe}_{3} \mathrm{O}_{4} @ \mathrm{Si} / \mathrm{Ph}-\mathrm{SO}_{3} \mathrm{H}$ was examined by thermal gravimetric analysis (TGA) and temperature-programmed oxidation-mass spectrometry (TPO-MS). The weight loss of $6 \%$ at around $150{ }^{\circ} \mathrm{C}$ was attributed to the loss of physically adsorbed water, with the weight remaining constant beyond this point up to $200{ }^{\circ} \mathrm{C}$ (Fig. 5(a)). Further weight loss events also occurred at 200,350 , and $600{ }^{\circ} \mathrm{C}$, with similar trends also observed in the ion current (Fig. 5(b)). The latter two losses was attributed to the decomposition of the residual oleic acid and phenyl groups (Fig. 5). These results indicated
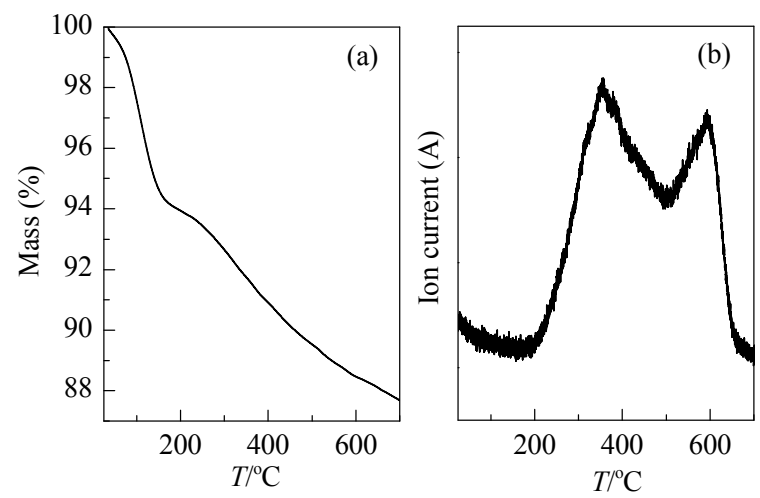

Fig. 5. Thermal analysis of $\mathrm{Fe}_{3} \mathrm{O}_{4} @ \mathrm{Si} / \mathrm{Ph}_{-} \mathrm{SO}_{3} \mathrm{H}$. (a) TGA; (b) TPO-MS. that the material had relatively high thermal stability and was stable under the reaction conditions $\left(<200^{\circ} \mathrm{C}\right)$.

With the $\mathrm{Fe}_{3} \mathrm{O}_{4} @ \mathrm{Si} / \mathrm{Ph}_{-} \mathrm{SO}_{3} \mathrm{H}$ material in hand, we proceeded to investigate its catalytic performance towards the dehydration of fructose (Table 2). Without the sulfonation step, the resulting $\mathrm{Fe}_{3} \mathrm{O}_{4} @ \mathrm{Si} / \mathrm{Ph}$ particles were effectively inactive and gave a fructose conversion of only $9.5 \%$. Based on the same amount of acid groups, A-15 gave a fructose conversion of $60.1 \%$ and an HMF yield of $16.7 \%$. Homogeneous $p$-toluenesulfonic acid showed a high efficiency for the transformation with a fructose conversion of $91.6 \%$ and an HMF yield of $56.4 \%$. When $\mathrm{Fe}_{3} \mathrm{O}_{4} @ \mathrm{Si} / \mathrm{Ph}-\mathrm{SO}_{3} \mathrm{H}$ was used, the reaction gave a fructose conversion of $96.3 \%$ with a HMF yield of $55.2 \%$ following $3 \mathrm{~h}$ at $100{ }^{\circ} \mathrm{C}$. This result was higher than that achieved with A-15 and comparable to that of homogenous $p$-toluenesulfonic acid, and was also better than those reported for several solid sulfonic acid catalysts such as $\mathrm{PS}-\mathrm{PP}-\mathrm{SO}_{3} \mathrm{H}$, PC-SO ${ }_{3} \mathrm{H}$, and Nafion (15)/MCF $[8,23,32]$. Furthermore, the TOF value for this catalyst was up to $164.5 \mathrm{~h}^{-1}$. The high efficiency of this catalyst may be attributed to the nanosize of the particles and their thin shells, which allowed for the acid sites to be effectively exposed on the outer surface of the particles. The $\mathrm{Fe}_{3} \mathrm{O}_{4} @ \mathrm{Si} / \mathrm{Ph}_{-} \mathrm{SO}_{3} \mathrm{H}$ particles had a surface area nearly four times greater than that of A-15 (Table 1). Although several other research efforts have been devoted to effectively exposing the acid sites by functionalizing porous materials (i.e., PS-PP-SO ${ }_{3} \mathrm{H}, \mathrm{PC}_{-} \mathrm{SO}_{3} \mathrm{H}$, and Nafion (15)/MCF), mass transfer limitations generally cause problems in these systems because the active sites are on the inner pore surface. For the $\mathrm{Fe}_{3} \mathrm{O}_{4} @ \mathrm{Si} / \mathrm{Ph}-\mathrm{SO}_{3} \mathrm{H}$ nanoparticles, the reactions occurred predominantly on the outside surface, which represents a favorable scenario for the substrate and the product, in terms of them being able to readily diffuse to and/or from the active sites, thus enhancing the conversion and preventing the occurrence of side-reactions involving the HMF at the acid sites.

Table 2

Conversion of fructose and yield of HMF over different acid catalysts.

\begin{tabular}{|c|c|c|c|}
\hline $\begin{array}{l}\text { Catalyst } \\
\text { Cat }\end{array}$ & Conversion (\%) & Yield (\%) & TOF $\left(h^{-1}\right)$ \\
\hline$\overline{\mathrm{Fe}_{3} \mathrm{O}_{4} @ \mathrm{Si} / \mathrm{Ph}}$ & 9.5 & trace & - \\
\hline $\mathrm{Fe}_{3} \mathrm{O}_{4} @ \mathrm{Si} / \mathrm{Ph}-\mathrm{SO}_{3} \mathrm{H}$ & 96.3 & 55.2 & 164.5 \\
\hline A-15 & 60.1 & 16.7 & 49.8 \\
\hline $\begin{array}{l}\text { p-toluenesulfonic } \\
\text { acid }\end{array}$ & 91.6 & 56.4 & 168.1 \\
\hline $\mathrm{Fe}_{3} \mathrm{O}_{4} @ \mathrm{Si} / \mathrm{Ph}-\mathrm{SO}_{3} \mathrm{H}^{\mathrm{a}}$ & $>99.0$ & 82.3 & 254.0 \\
\hline $\mathrm{Fe}_{3} \mathrm{O}_{4} @ \mathrm{Si} / \mathrm{Ph}-\mathrm{SO}_{3} \mathrm{H}^{\mathrm{a}, \mathrm{b}}$ & $>99.0$ & 78.9 & 243.5 \\
\hline $\mathrm{Fe}_{3} \mathrm{O}_{4} @ \mathrm{Si} / \mathrm{Ph}-\mathrm{SO}_{3} \mathrm{H}^{\mathrm{a}, \mathrm{c}}$ & $>99.0$ & 79.5 & 245.4 \\
\hline $\mathrm{PC}-\mathrm{SO}_{3} \mathrm{H}^{\mathrm{d}}$ & - & 65.2 & - \\
\hline Nafion(15)/MCFe & 84.4 & 78.6 & 28.2 \\
\hline PS-PP-SO ${ }_{3} \mathrm{H}^{\mathrm{f}}$ & 27 & 20.3 & 0.69 \\
\hline
\end{tabular}

Reactions were carried out with $0.02 \mathrm{~g}$ fructose and catalyst (acid amount: $0.12 \mu \mathrm{mol} \mathrm{H}+$ ) in $1 \mathrm{~mL}$ DMSO for $3 \mathrm{~h}$ at $100^{\circ} \mathrm{C}$ in Ar.

a $110^{\circ} \mathrm{C}$.

bSecond recycle.

cThird recycle.

${ }^{\mathrm{d}}$ Reaction conditions: $0.1 \mathrm{~g}$ fructose, molar ratio of fructose to acidic site at $10,5 \mathrm{~g}$ DMSO, $110^{\circ} \mathrm{C}, 4 \mathrm{~h}$ [8].

e Reaction conditions: fructose in DMSO (3 wt $\%, 12.5 \mathrm{~g}$ ), $0.03 \mathrm{mmol} \mathrm{H}$, $90^{\circ} \mathrm{C}, 2 \mathrm{~h}[32]$.

${ }^{\mathrm{f}}$ Reaction conditions: $10 \mathrm{~g}$ fructose, $2 \mathrm{~g}$ catalyst (acidity: $1.8 \mathrm{mmol} / \mathrm{g}$ catalyst), MIBK/water $(100 \mathrm{~mL})=3,135^{\circ} \mathrm{C}, 4.5 \mathrm{~h}$ [23]. 

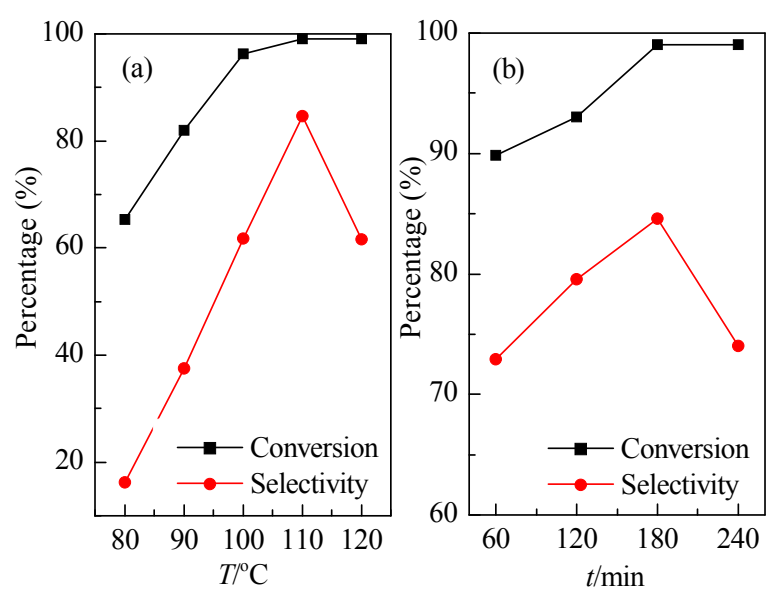

Fig. 6. (a) Effect of temperature on the fructose dehydration reactions over the $\mathrm{Fe}_{3} \mathrm{O}_{4} @ \mathrm{Si} / \mathrm{Ph}-\mathrm{SO}_{3} \mathrm{H}$ catalyst in $3 \mathrm{~h}$. (b) Time-on-stream profile at $110^{\circ} \mathrm{C}$.

A series of optimization experiments were conducted to determine the best reaction conditions for the dehydration of fructose over the $\mathrm{Fe}_{3} \mathrm{O}_{4} @ \mathrm{Si} / \mathrm{Ph}-\mathrm{SO}_{3} \mathrm{H}$ catalyst (Fig. 6). Increasing the temperature led to a gradual increase in the fructose conversion, with a conversion of $99 \%$ being achieved at $110{ }^{\circ} \mathrm{C}$ after $3 \mathrm{~h}$. Further increases in the temperature did not lead to further increases in the conversion, which effectively reached a plateau at $110{ }^{\circ} \mathrm{C}$. Furthermore, the HMF selectivity increased from $16 \%$ at $80{ }^{\circ} \mathrm{C}$ to $82 \%$ at $110{ }^{\circ} \mathrm{C}$, although further increasing the temperature to $120{ }^{\circ} \mathrm{C}$ led to a decrease in the $\mathrm{HMF}$ selectivity to $62 \%$. These results indicated that the use of a high temperature would lead to by-products, such as furfural and acetic acid. Experiments to determine the effects of different reaction times were conducted at $110^{\circ} \mathrm{C}$. A reaction time of $3 \mathrm{~h}$ gave an HMF selectivity of $82 \%$. Further extending the reaction time, however, led to HMF being converted to levulinic acid, formic acid, and humic acid under acid conditions, and a lower yield of HMF [33]. Following the optimization experiments, the reaction gave a fructose conversion of $99 \%$ and an $\mathrm{HMF}$ yield of $82.3 \%$ following $3 \mathrm{~h}$ at $110^{\circ} \mathrm{C}$ (Table 2).

Furthermore, after the reaction, the magnetic $\mathrm{Fe}_{3} \mathrm{O}_{4} @ \mathrm{Si} / \mathrm{Ph}$ $\mathrm{SO}_{3} \mathrm{H}$ catalyst could be readily separated from the mixture by magnetic force. Figure 7 clearly shows that an aqueous suspension of the catalyst rapidly became transparent following the

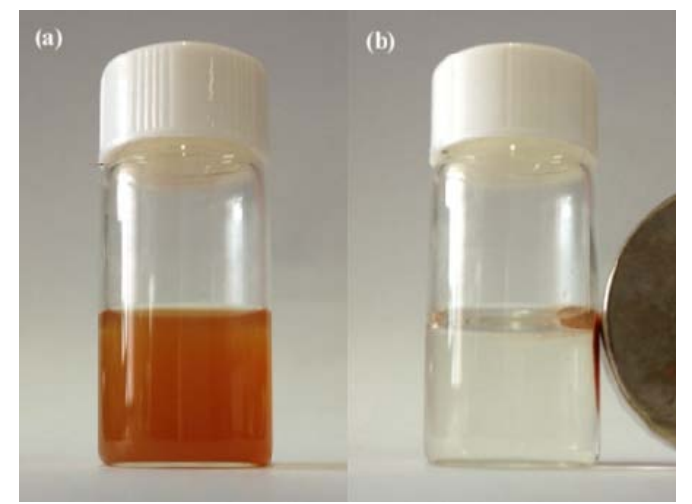

Fig. 7. Images of the $\mathrm{Fe}_{3} \mathrm{O}_{4} @ \mathrm{Si} / \mathrm{Ph}-\mathrm{SO}_{3} \mathrm{H}$ catalyst before (a) and after (b) the separation using magnetic force. application of magnetic force. The used catalyst was then washed with hot water and ethanol several times before being dried at $100{ }^{\circ} \mathrm{C}$ to prepare it for use in the next run. The catalytic activities of the recycled $\mathrm{Fe}_{3} \mathrm{O}_{4} @ \mathrm{Si} / \mathrm{Ph}-\mathrm{SO}_{3} \mathrm{H}$ catalyst (after being recycled two times) were comparable to that of the fresh catalyst (Table 2). These results indicated that the $\mathrm{Fe}_{3} \mathrm{O}_{4} @ \mathrm{Si} /$ $\mathrm{Ph}-\mathrm{SO}_{3} \mathrm{H}$ catalyst was a relatively stable heterogeneous catalyst.

\section{Conclusions}

We have successfully synthesized a magnetic acid catalyst, $\mathrm{Fe}_{3} \mathrm{O}_{4} @ \mathrm{Si} / \mathrm{Ph}_{-} \mathrm{SO}_{3} \mathrm{H}$, consisting of an $\mathrm{Fe}_{3} \mathrm{O}_{4}$ core with a sulfonic acid functionalized silica shell using a nanocoating method, which allowed for the acid sites to be effectively exposed during the reaction and the catalyst itself to be readily separated from the reaction mixture upon completion of the reaction using magnetic force. This catalytic system showed higher activity than conventional solid sulfonic acid catalysts and comparable activity to homogeneous acid catalysts towards the dehydration of fructose to HMF. Furthermore, the catalyst could be easily separated by magnetic force and reused without any significant loss in activity.

\section{References}

[1] Shi S, Guo H J, Yin G C. Catal Commun, 2011, 12: 731

[2] Jia X Q, Ma J P, Che P H, Lu F, Miao H, Gao J, Xu J. J Energy Chem, 2013, 22: 93

[3] Tong X L, Ma Y, Li Y D. Carbohydr Res, 2010, 345: 1698

[4] Kim Y H, Shin S, Yoon H J, Kim J W, Cho J K, Lee Y S. Catal Commun, 2013, 40: 18

[5] Li Y, Liu H, Song C H, Gu X M, Li H M, Zhu W S, Yin S, Han C R. Bioresour Technol, 2013, 133: 347

[6] Wang F F, Wu H Z, Liu C L, Yang R Z, Dong W S. Carbohydr Res, 2013, 368: 78

[7] Ma J P, Yu W Q Wang M, Jia X Q, Lu F, Xu J. Chin J Catal (马继平, 于 维强, 王敏, 贾秀全, 路芳, 徐杰. 催化学报), 2013, 34: 492

[8] Wang L, Zhang J, Zhu L F, Meng X J, Xiao F S. J Energy Chem, 2013, 22: 241

[9] Villa A, Schiavoni M, Fulvio P F, Mahurin S M, Dai S, Mayes R T, Veith G M, Prati L. J Energy Chem, 2013, 22: 305

[10] Binder J B, Raines R T. J Am Chem Soc, 2009, 131: 1979

[11] Sievers C, Musin I, Marzialetti T, Valenzuela Olarte M B, Agrawal P K, Jones C W. ChemSusChem, 2009, 2: 665

[12] Asghari F S, Yoshida H. Ind Eng Chem Res, 2006, 45: 2163

[13] Yang Y, Hu C W, Abu-Omar M M. Green Chem, 2012, 14: 509

[14] Deng T S, Cui X J, Qi Y Q, Wang Y X, Hou X L, Zhu Y L. Chem Commun, 2012, 48: 5494

[15] Ren Q H, Huang Y Z, Ma H, Wang F, Gao J, Xu J. Bioresources, 2013, 8: 1563

[16] Li C Z, Zhao Z K, Cai H L, Wang A Q, Zhang T. Biomass Bioenergy, 2011, 35: 2013

[17] Ordomsky V V, Sushkevich V L, Schouten J C, van der Schaaf J, Nijhuis T A.J Catal, 2013, 300: 37

[18] O'Neill R, Ahmad M N, Vanoye L, Aiouache F. Ind Eng Chem Res, 2009, 48: 4300

[19] Yan H P, Yang Y, Tong D M, Xiang X, Hu C W. Catal Commun, 2009, 10: 1558

[20] Qi X H, Watanabe M, Aida T M, Smith R L Jr. Green Chem, 2009, 11: 1327 


\section{Graphical Abstract}

Chin. J. Catal., 2014, 35: 703-708 doi: 10.1016/S1872-2067(12)60739-6

\section{Nanocoating of magnetic core with sulfonic acid functionalized shells for the catalytic dehydration of fructose to 5-hydroxymethylfurfural}

Xiaochen Zhang, Min Wang, Yehong Wang, Chaofeng Zhang, Zhe Zhang, Feng Wang*, Jie Xu*

Dalian Institute of Chemical Physics, Chinese Academy of Sciences; Graduate University of Chinese Academy of Sciences

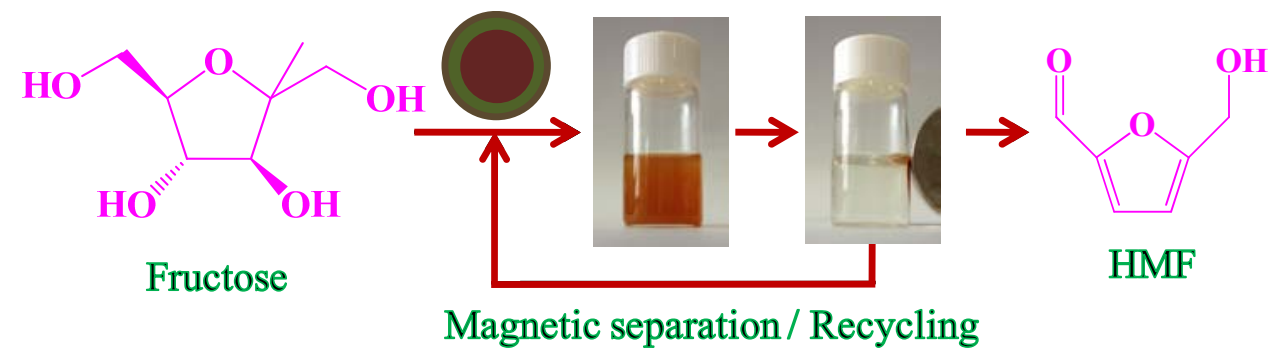

A magnetically recyclable acid catalyst consisting of an $\mathrm{Fe}_{3} \mathrm{O}_{4}$ core and a thin sulfonic acid functionalized silica shell has been prepared using a reverse microemulsion method and subsequently used for the dehydration of in fructose to 5-hydroxymethylfurfural (HMF). This process gave a fructose conversion of approximately $99 \%$ and an $82 \%$ yield of $\mathrm{HMF}$ after $3 \mathrm{~h}$ in DMSO at $110^{\circ} \mathrm{C}$.

[21] Guo X C, Cao Q, Jiang Y J, Guan J, Wang X Y, Mu X D. Carbohydr Res, 2012, 351: 35

[22] Qi X H, Guo H X, Li L Y, Smith R L Jr. ChemSusChem, 2012, 5: 2215

[23] Ordomsky V V, Schouten J C, van der Schaaf J, Nijhuis T A. Chem Eng J, 2012, 207-208: 218

[24] Narita A, Naka K, Chujo Y. Colloids Surf A, 2009, 336: 46

[25] Maity D, Agrawal D C.J Magn Magn Mater, 2007, 308: 46

[26] Sun Y B, Ding X B, Zheng Z H, Cheng X, Hu X H, Peng Y X. Eur Polym $J, 2007,43: 762$

[27] Singh N, Kumar R, Sachan P K. Chem Eng, 2013, 2013: 1
[28] Wang M, Chen C, Ma J P, Xu J.J Mater Chem, 2011, 21: 6962

[29] Cannas C, Musinu A, Ardu A, Orrù F, Peddis D, Casu M, Sanna R, Angius F, Diaz G, Piccaluga G. Chem Mater, 2010, 22: 3353

[30] Chen C, Zhang Q H, Gao J, Zhang W, Xu J. J Nanosci Nanotechnol, 2009, 9: 1589

[31] Zhang X C, Zhang Z, Wang F, Wang Y H, Song Q, Xu J.J Mol Catal A, 2013, 377: 102

[32] Huang Z, Pan W Y, Zhou H B, Qin F, Xu H L, Shen W. ChemSusChem, 2013, 6: 1063

[33] Zhang J, Weitz E. ACS Catal, 2012, 2: 1211

\section{磺酸官能化的磁性核壳结构的纳米材料用于果糖脱水制备5-羟甲基糠醛

\author{
a国科学院大连化学物理研究所, 辽宁大连 116023 \\ 中国科学院大学, 北京 100049
} \\ 张晓辰 ${ }^{\mathrm{a}}$, 王 敏 ${ }^{\mathrm{a}}$, 王业红 ${ }^{\mathrm{a}}$, 张超峰 ${ }^{\mathrm{a}, \mathrm{b}}$, 张 哲 ${ }^{\mathrm{a}, \mathrm{b}}$, 王 峰 ${ }^{\mathrm{a},{ }^{*}}$, 徐 杰 $^{\mathrm{a}, \#}$}

摘要: 通过反相微乳液法制备了以 $\mathrm{Fe}_{3} \mathrm{O}_{4}$ 为核, 磺酸官能化的硅基材料为壳层的磁性酸性催化剂. 首先制备纳米 $\mathrm{Fe}_{3} \mathrm{O}_{4}$ 磁核, 然后 涂层包覆苯基修饰的纳米级硅层, 最后进行苯基磺化修饰, 制得固体酸催化剂 $\mathrm{Fe}_{3} \mathrm{O}_{4} @ \mathrm{Si} / \mathrm{Ph}-\mathrm{SO}_{3} \mathrm{H}$. 在果糖脱水制备5-羟甲基糠醛 反应中, 该催化剂表现出较好的催化活性, 优于传统催化剂 $\mathrm{A}-15$, 且与均相无机酸催化活性相当. 当采用二甲基亚砜作溶剂, 在 $110{ }^{\circ} \mathrm{C}$ 下反应 $3 \mathrm{~h}$, 果糖转化率达到 $99 \%, 5$-差甲基糠醛收率为 $82 \%$. 另外, 该催化剂经磁法回收后可多次重复使用.

关键词: 磁性粒子; 纳米催化剂; 果糖脱水; 5-羊圣甲基糠醛; 磺酸

收稿日期: 2013-09-21. 接受日期: 2013-10-23. 出版日期: 2014-05-20.

*通讯联系人. 电话/传真: (0411)84379762; 电子信箱: wangfeng@dicp.ac.cn

通讯联系人. 电话/传真: (0411)84379245; 电子信箱: xujie@dicp.ac.cn

基金来源：国家自然科学基金 $(21073184,21273231,21233008)$; 中国科学院“百人计划”.

本文的英文电子版由Elsevier出版社在ScienceDirect上出版(http://www.sciencedirect.com/science/journal/18722067). 